\title{
Supply Chain Management Systems and Curriculum Reviews: What Are We Teaching About Supply Chain Management Systems? Do We Need to Modify Our Curriculums?
}

\author{
Joseph Walden \\ Correspondence: Joseph Walden, The University of Kansas, USA. E-mail: joewalden@ku.edu
}

Received: Apr. 26, 2020

Accepted: May 14, 2020

Online Published: May 19, 2020

doi:10.11114/ijce.v3i2.4861

URL: https://doi.org/10.11114/ijce.v3i2.4861

\begin{abstract}
The recent COVID-19 pandemic has brought the supply chain to the attention of everyone. In order to make supply chains work effectively and efficiently, a number of automated supply chain management systems are needed. This paper looks at the need to conduct curriculum reviews in order to ensure that the students in supply chain programs are not being harmed by the lack of exposure to the various systems needed in the supply chain. The analysis looks at the systems required for an Enterprise Certification compared to the systems reflected in a sample of supply chain management syllabi. The conclusions include the need to conduct curriculum reviews on a regular basis to ensure the best possible education of the students. This recommendation is critical for all education systems and not just supply chain management systems courses.
\end{abstract}

Keywords: supply chain management, supply chain systems, curriculum review, curriculum design

\section{Introduction}

The COVID-19 pandemic has brought the supply chain to the forefront and to the attention of everyone. For supply chains to run effectively and efficiently, a number of automated systems are needed.

A pilot study was conducted in 2017 to determine the need to look at supply chain management curriculums with a follow on study conducted in 2018 on supply chain management curriculum development The previous studies compared a small sample of syllabi for supply chain management courses to a sample of job announcements. The pilot study showed enough discrepancy in what was listed as relevant topics in the syllabi and what industry was asking for in graduates applying for supply chain jobs. Based on the pilot study, in 2018, I conducted a much more detailed study about what was being taught in supply chain management introductory courses. That study started with a database of over four hundred supply chain management course syllabi. The syllabi for that study were narrowed down to seventy-eight syllabi that met the criteria for introductory courses. The key words from the syllabi were compared against the key words from a sample of one hundred and forty job announcements randomly selected over a five-month period. The 2018 study provided a strong foundation in supply chain management courses (2018). The 2018 database has now been expanded to just under 500 course syllabi for supply chain management courses and has expanded its scope to include international course offerings as well as domestic USA courses.

\subsection{Supply Chain Systems Curriculum Development}

The COVID-19 pandemic has brought the supply chain to the forefront and to the attention of everyone. For supply chains to run effectively and efficiently, a number of automated systems are needed.

A pilot study was conducted in 2017 to determine the need to look at supply chain management curriculums with a follow on study conducted in 2018 on supply chain management curriculum development The previous studies compared a small sample of syllabi for supply chain management courses to a sample of job announcements. The pilot study showed enough discrepancy in what was listed as relevant topics in the syllabi and what industry was asking for in graduates applying for supply chain jobs. Based on the pilot study, in 2018, I conducted a much more detailed study about what was being taught in supply chain management introductory courses. That study started with a database of over four hundred supply chain management course syllabi. The syllabi for that study were narrowed down to seventy-eight syllabi that met the criteria for introductory courses. The key words from the syllabi were compared against the key words from a sample of one hundred and forty job announcements randomly selected over a five-month period. The 2018 study provided a strong 
foundation in supply chain management courses (2018). The 2018 database has now been expanded to just under 500 course syllabi for supply chain management courses and has expanded its scope to include international course offerings as well as domestic USA courses. This study builds on the 2017 and 2018 studies and because of the COVID-19 pandemic that identified supply chain issues, the study of what systems are used and taught in the supply chain management courses has become a hot topic for improving supply chain management performance in the future.

The previous studies identified shortfalls in the overall supply chain management curriculums. The size (78 syllabi/courses) of the full blown 2018 study was deemed statistically large enough to infer that there are significant issues in what is taught in supply chain management courses and what industry is asking for in the job announcements for new supply chain management graduates. As a continuation of the previous pilot study and full blown study, a series of studies was launched to look at each of the major areas of supply chain management education identified in the 2018 study. This study is a continuation of the studies of the major supply chain management topics and is focused on developing curriculum for teaching supply chain management systems. As the world becomes more and more dependent on automated systems to run supply chains, the starting point for this study was to look at what is being taught according to the syllabi used in the study and what industries are using for supply chain management automation. The goal was to determine if there is a shortfall in the education process thus putting graduates at a disadvantage in the job search process.

\subsection{Literature Review}

In 2007, Li and Wang recognized the importance of supply chain management and established the need for an integrated approach to teaching supply chain management systems in academia, "Supply chain management (SCM) has become an important management paradigm. As supply chain members are often separate and independent economic entities, a key issue in SCM is to develop mechanisms that can align their objectives and coordinate their activities so as to optimize system performance" (2007). In 2008, Sarimveis, et al., came to the same conclusions and pointed to the necessity to have the right systems in place to manage the supply chain (2008) and the need to understand how these systems work which points to the need to have supply chain systems properly covered in undergraduate programs.

Kakhki and Gargeya stated that research in academia has studied the "inter-connectedness between information and communication technologies and production/operations/supply chain management" (2018). Their study looked at 1500 papers written about logistics and supply chain management systems over the past 40 years. Their conclusion points to the need for my study by stating: "The time is ripe for a systematic analysis in creating a comprehensive framework for studying the two topic and key inter-disciplinary areas." Bellamy and Basole came to the same conclusion six years earlier (2012). Chandra and Kumar researched the development of supply chain management curriculums in 2006 and recommended an integrated approach to teaching supply chain management systems (2006).

Sweeney, Campbell and Mundy (2010) identified the shortcoming and need for proper supply chain systems education from a graduate perspective when they reported "Incorporating commercial software in university programs presents a myriad of challenges and therefore is rarely done. However, providing students with in-depth knowledge of commercial logistics and supply chain management software improves their understanding of supply chain issues and provides a key differentiator in the marketplace. Modeling real-world supply chains using commercial software enhances student's education by providing relevant experiential exposure to real-world problems and decision-support tools." This also points to the need for this study.

A google scholar search revealed 2,000 papers and books written on supply chain systems in the past three years. When the search was refined to supply chain systems and curriculum the list was quickly narrowed to sixty papers that mentioned those terms or roughly $3 \%$ of the documents. Only three of the studies actually looked at the development of supply chain management systems curriculum. This would insinuate that there has not been a lot of research into systems but not as much research into systems curriculum and only three attempts to look at the curriculum and two of those (Bellamy and Basole, 2012, and Chandra and Kumar, 2006) were done years ago. While some of these studies have been around for over a decade, the consensus appears to be the need to have a comprehensive study of what is being taught in supply chain management systems courses and the need for this study to look at the adequacy of what is being taught when compared to the systems knowledge necessary to integrate and operate supply chain management systems using the Association for Supply Chain Management enterprise certification program as the baseline for what systems are necessary to run a supply chain in the $21^{\text {st }}$ Century.

Studies back to 1978 (Gilmour, 1978) have insinuated that the curriculums for supply chain management may not be current or relevant and more recent papers confirm that the issue is still with us (Alakin, Haung, and Willems (2016); Jordan and Bak (2016); Birou, et al., (2016)). While Schatte, et al. (2018) tell us that the first step of curriculum development/review is to identify the problem and establish a needs assessment. In developing equipment requirements for the US Army when I was in research and development, we called this the Operational Needs Statement. The problem and operational needs statement for this research is: what do students need to be exposed to as an undergraduate in order to be prepared to perform in the real world upon graduation? 


\subsection{Approach}

The original study focus has now shifted to looking at the key areas of supply chain management identified in the previous studies. A 2019 follow on study looked at the coverage of reverse logistics in supply chain management academic courses (2019). The focus of this paper is what is being taught and what should be taught in supply chain management systems courses.

Just what is a supply chain system? The best definition I could find states: "Supply chain management systems, simply defined, are a network of businesses linked together to provide materials and services to an end user. The goal of these systems is to coordinate functions and strategies, throughout a company, and across businesses, to improve the performance of all parties involved" (2020). The industry accepted standard for supply chain management is the Supply Chain Operations Reference (SCOR) model. ${ }^{1}$ This model states that the supply chain runs from the suppliers' suppliers to the customers' customers and includes six basic functions inherent in every supply chain. Those functions are plan, source, make, deliver, return, and enable. It is the enable function that includes all of the systems necessary for the other five functions to operate properly. It is these systems that this paper is focusing on.

Almost every supply chain management program has a course dedicated to supply chain systems. Therefore, the focus of this research is:

a) What is being taught in the supply chain systems courses.

b) What textbook (if any) is used to teach these courses.

c) What systems are taught.

d) What systems in the supply chain management field should be taught.

The goal of this four-prong approach was to determine if we are teaching what the students need to know in order to set the conditions for success in the job search and in the corporate world upon graduation? What is meant by "setting the conditions" for success. In the Military, the concept of setting the conditions means to do all the proper planning based on all available resources and inputs in order to develop operational plans and supporting contingency plans. In the academic context, setting the conditions for success means that we are providing our students with the best possible education in order to prepare them for the interviewing process to help them stand out in the crowd of applicants while also preparing them for the challenges of the new career. Without setting these conditions for success, the graduates from the supply chain management programs will not have the necessary situational awareness of the operations of the supply chains or how to effectively pass information in the supply chain. The need to establish conditions for success are also critical in the classroom. The lesson from the Military is to define success and then carefully plan those steps and interim conditions that are necessary for success. In the classroom, the same is true. Curriculum developers and faculty need to define success. For this study, success is defined as graduates prepared for the jobs that they will get after graduation. The interim conditions in the supply chain world are those areas that graduates should understand and master as part of their supply chain management and business management studies.

"In the Military, situational awareness is knowing what is going on in front of you, beside you and behind you. On the battlefield, situational awareness is necessary to prevent surprises and defeat by the enemy. In the supply chain management classroom, situational awareness consists of knowing the basics of supply chain management as well as the emerging concepts that students will need to understand to be successful in the commercial world. The analysis of this study will provide situational awareness of what is being taught and what should be taught to set the conditions for success of supply chain management students in particular and business management students in general in the job market" (2018).

Sun Tzu (1993), in his book The Art of War, spoke of the seven laws of warfare. One of these seven laws of warfare is knowledge. While this paper is not about warfare, there is an interesting corollary here in that one of the seven irrefutable laws of warfare according to Sun was knowledge. When applying the writings of Sun Tzu to $21^{\text {st }}$ Century supply chains, one of the irrefutable laws of successful supply chains is current, relevant knowledge. It was with this irrefutable law of supply chain management in mind and the goal to see what knowledge is transferred to the students concerning supply chain systems that this research project was conducted.

\subsection{Curriculum Development}

What is the link between looking at supply chain management systems and curriculum development? How long has it been since a program has looked at their curriculum and reviewed what is being taught? One program contacted admitted that a full curriculum review had not been completed in the ten years that the program was offered. Another seemed proud of a case study on supply chain systems from 1995. This should raise red flags to someone. Think about the changes in

\footnotetext{
${ }^{1}$ For more on the SCOR model, go to: http://www.apics.org/apics-for-business/frameworks/scor
} 
personal computing since 1995 and then think about the rapid changes in automation and systems in the past twenty-five years in corporate systems. These changes would indicate that a 1995 case study cannot be relevant. These two anecdotal inferences served as the impetus to look at the taught curriculum for supply chain management systems.

\section{Methodology}

\subsection{Syllabi Collection}

The syllabi in the database were collected via several sampling techniques:

a. Sampling Strategy 1. Convenience: one of my responsibilities is to review syllabi for consideration for credit for courses taken at other schools. This provides a steady stream of syllabi from programs globally.

b. Sampling Strategy 2: Internet Search: an internet search was conducted using the terms "Supply Chain Management Syllabus" and "Supply Chain Management Systems Syllabus." This strategy provided a large number of readily available syllabi from programs and schools both domestically and internationally.

c. Sampling Strategy 3: Direct Contact: although this could fit under the umbrella of a convenience strategy, in this strategy, I reached out to peers and asked for copies of their syllabi, primarily in the systems arena.

d. Sampling Strategy 4: Snowballing: a corollary strategy from the direct contact strategy was the snowballing effect when peers contacted their peers to provide me with copies of their syllabi. This networking benefit provided a wider sample of syllabi.

e. Sampling Strategy 5: Search of CourseHero.com: this valuable resource provided a wide variety of syllabi. Within CourseHero.com, I searched initially for "Supply Chain Management Syllabi" and then refined the search to "Supply Chain Management Systems Syllabi."

\subsection{Syllabi Selection}

These sampling strategies provided the database of five hundred syllabi. The syllabi covered general supply chain management classes, specific topics in supply chain management, graduate classes in supply chain management, directed studies in supply chain management and supply chain management research classes. This created a need to narrow down the syllabi needed for this study. The syllabi were narrowed down in a similar method used in the 2018 study on supply chain management introductory courses and the 2019study of reverse logistics courses.

a. Selection Strategy 1: All syllabi for graduate courses were eliminated from the study database to parallel previous studies focusing only on undergraduate courses.

b. Selection Strategy 2: All introductory supply chain management course syllabi were eliminated. This was done to remove generic supply chain management courses.

c. Selection Strategy 3: The remaining syllabi were then narrowed down to just those courses that had supply chain management systems in their titles. This does not mean that other supply chain management classes are not teaching systems, this is just a way of narrowing down the focus of the project. This left the sample a little more manageable and narrowed the scope to twenty syllabi from twenty different schools in the USA, Europe, Canada, Viet Nam, Turkey, New Zealand, and South Africa.

\section{Analysis and Discussion}

Each syllabus was then carefully analyzed and coded for supply chain management systems that were covered in the syllabi. This provided a list of systems specifically addressed in the syllabi and the corresponding number of syllabi that covered those topics. The Association for Supply Chain Management Enterprise Certification book was used to identify relevant key terms and systems. The last phase of the data capture was to review literature and the resources of the Association for Supply Chain Management, the Council of Supply Chain Management Professionals, and the Institute for Supply Management, to include their certification preparation materials to identify those system that the leading supply chain management professional organizations reflect as relevant to successful supply chain management.

Although the syllabi were titled "Supply Chain Management Systems," three of the syllabi did not specifically address any particular system other than to address "Network Design." And while network design is definitely a critical aspect of systems management, there was no mention in the syllabi under network design of any particular system needed in the network. The quantitative data capture revealed the following specifically addressed topics in supply chain management systems courses as shown in Table 1: 
Table 1. Supply Chain Management Systems listed in syllabi

\begin{tabular}{|c|c|c|c|}
\hline Topic & $\begin{array}{l}\text { \# of Syllabi } \\
\text { appearing in }\end{array}$ & Topic & $\begin{array}{l}\text { \# of Syllabi } \\
\text { appearing in }\end{array}$ \\
\hline Inventory Management & 5 & quality management systems & 1 \\
\hline ERP & 4 & Knowledge management & 1 \\
\hline SAP & 4 & Mobile computing & 1 \\
\hline Linear Programming & 4 & SAS & 1 \\
\hline $\begin{array}{l}\text { Materials Requirements } \\
\text { Planning (MRP) }\end{array}$ & 4 & Advanced Planning Systems & 1 \\
\hline Procurement in SAP & 3 & Transportation Management & 1 \\
\hline $\begin{array}{l}\text { Customer Relationship } \\
\text { Management }\end{array}$ & 3 & Distribution Management Systems & 1 \\
\hline $\begin{array}{c}\text { Warehouse Management } \\
\text { System }\end{array}$ & 2 & Supplier Management Systems & 1 \\
\hline Network design & 2 & Human Resources Management & 1 \\
\hline Production Planning Software & 2 & Product Life Cycle Management & 1 \\
\hline Oracle & 2 & $\begin{array}{l}\text { Manufacturing Resource Planning } \\
\text { (MRP-II) }\end{array}$ & 1 \\
\hline $\begin{array}{l}\text { Manufacturing Execution } \\
\text { System }\end{array}$ & 2 & Workflow Software & 1 \\
\hline designing networks & 1 & $\begin{array}{l}\text { Distribution Requirements } \\
\text { Planning }\end{array}$ & 1 \\
\hline Supply Chain Performance & 1 & Order Management Systems & 1 \\
\hline Forecasting in SAP & 1 & Supply chain systems vendors & 1 \\
\hline
\end{tabular}

Without more detailed information in the syllabi, it is hard to determine if the courses that listed Enterprise Resource Planning programs (ERP), or specifically identified ERP programs such as SAP or Oracle covered the other supply chain systems under those umbrellas. Given the number of class periods dedicated to ERP/SAP/Oracle (an average of 3 class periods), it would be logical to assume that the other critical supply chain management systems are not covered in any detail in those courses. Questions to course authors indicated that their course focused on the intricacies of the ERP program and not the specific systems themselves.

The ASCM website listed the systems shown in Table 2 as the systems that must be mastered in order to receive their Corporate Enterprise Certification. (ASCM, 2020). While we in academia should not be in the business of trying to get companies certified in systems, this listing of systems considered important by the Association for Supply Chain Management at least provides a guide to the systems that the largest international supply chain professional organization feels are important. This at least provides a baseline for measuring what is taught against what is needed in the way of systems knowledge or understanding by the graduates of supply chain programs. 
Table 2. ASCM Listed Supply Chain Management Systems for Certification (ASCM, 2020)

\begin{tabular}{c|c}
\hline Facility Master Planning & $\begin{array}{c}\text { Process Invoice Quote, Receive, Enter and } \\
\text { Validate }\end{array}$ \\
\hline Lean Planning & $\begin{array}{c}\text { Electronic Returns Tracking and Returns } \\
\text { Management }\end{array}$ \\
\hline Supply Network Planning & Warehouse management systems \\
\hline Modal Optimization & Electronic Returns Tracking and Returns \\
Management
\end{tabular}

The predominant textbook for the courses reviewed and analyzed was a custom textbook. Therefore, this part of the analysis did not produce the desired outcome of identifying a common textbook for teaching supply chain management systems. This by itself may be an indication that there is a shortfall in the education process for teaching supply chain management systems.

3.1 Breaking Down the Systems Using the Industry Accepted Supply Chain Functions of the Supply Chain Operations Reference Model (SCOR)

Let's break the analysis down using the SCOR model's five operational functions of Plan, Source, Make, Deliver and Return. In doing so the analysis will look at the systems (enablers) that fall under those five areas using the ASCM enterprise certification model.

\subsubsection{Plan}

Planning is the foundation of any operation and certainly a critical aspect to successful supply chain operations. The failures of supply chains during the COVID-19 pandemic has helped to emphasize the criticality of this function in order to set the conditions for success in supply chain management. Under the Plan function of the supply chain the systems in Table 3 are required to successfully plan supply chain management operations. 
Table 3. Plan Systems Required

\begin{tabular}{l|l}
\hline Plan: & \\
\hline Continuous Improvement & $\begin{array}{l}\text { Manufacturing } \\
\text { Improvements for Return Reduction }\end{array}$ \\
\hline Distribution Planning Systems & Modal Optimization \\
\hline $\begin{array}{l}\text { Extend Inventory Planning using } \\
\text { Collaboration (Key Suppliers and } \\
\text { Customers) }\end{array}$ & MRP \\
\hline Facility Master Planning & MRP-II \\
\hline Improve S\&OP Process & Production Planning Systems \\
\hline Inventory optimization systems & $\begin{array}{l}\text { Supply Chain and Network } \\
\text { Optimization }\end{array}$ \\
\hline Lean Manufacturing & Supply Network Planning \\
\hline Lean Planning & Waste Management and Disposal \\
\hline Manufacturing Execution Systems & \\
\hline
\end{tabular}

The systems that are discussed in the sample syllabi include: Advanced Planning Systems, Workflow Software, Supply Chain Performance, Scheduling Software, Quality Management Systems, Production Planning Software, Network Design, Knowledge Management and ERP/SAP/SAS/Oracle. The lack of detail in most syllabi on the contents of what is taught concerning ERP/SAP/SAS/Oracle does not reveal if the classes discuss the individual functions involving planning. What is does reveal is a shortfall of specific instruction in this key area of supply chain management systems.

3.1.2 Source

Sourcing includes "the activities involved in scheduling product deliveries, receiving products, verifying products and authorizing supplier payment" (Blackstone, 2020). Also related to the function of Source from the SCOR Model is procurement: "the business functions of procurement, planning, purchasing, inventory control, traffic, receiving, incoming inspection, and salvage operations" (Blackstone, 2020). Using these industry standard definitions, sourcing systems includes the systems shown in Table 4:

Table 4. Source Supply Chain Systems Requirements

\begin{tabular}{l|l}
\hline Lean Planning & Responsible Sourcing \\
\hline Supply Network Planning & Sustainable Sourcing \\
\hline Modal Optimization & Supplier Diversity \\
\hline $\begin{array}{l}\text { Extend Inventory Planning using } \\
\text { Collaboration (Key Suppliers and Customers) }\end{array}$ & Waste Management and Disposal \\
\hline Supply Chain and Network Optimization & $\begin{array}{l}\text { Process Invoice Quote, Receive, Enter and } \\
\text { Validate }\end{array}$ \\
\hline Improve Sales \& Operations Planning Process & Continuous Improvement \\
\hline $\begin{array}{l}\text { Optimize Sourcing Decisions to Local Source } \\
\text { Point }\end{array}$ & Inventory optimization systems \\
\hline Supplier Research & Order Management Systems \\
\hline
\end{tabular}

The systems related to procurement/sourcing listed in the syllabi are: Network Design, Customer Relationship Management, Procurement in SAP, Product Life Cycle, Supply Chain Systems Vendors and Workflow Software. This would indicate a shortfall in teaching the systems necessary to properly source and procure in the supply chain. These systems may be covered in procurement or supplier management courses but should at least be mentioned in the supply chain management systems courses. A future study into procurement courses will be conducted. 


\subsubsection{Make}

In every supply chain something must be made from raw materials. The systems shown in Table 5 are necessary to support the make function of supply chain management.

Table 5. Supply Chain Management Systems to Support the Make Function in the SCOR Model

\begin{tabular}{l|l}
\hline Advanced Planning Systems & Product Life Cycle Management \\
\hline Forecasting in SAP & Production Planning Software \\
\hline Manufacturing Execution System & Quality Management Systems \\
\hline Manufacturing Resource Planning (MRP-II) & Scheduling software \\
\hline Order Management Systems & Workflow Software \\
\hline
\end{tabular}

When reviewing the syllabi, the systems that are covered in the systems courses to any extent are: Materials Requirements Planning (MRP), Manufacturing Execution Systems, Forecasting in SAP, quality management systems, knowledge management systems, Advanced Planning Systems, Product Life Cycle management, Manufacturing Resource Planning (MRP-II), workflow software, order management systems, scheduling software. It would appear that the Make function or manufacturing aspect of supply chain management may be the most adequately covered set of systems. This may stem from the precursor to supply chain management in most schools - Operations Management. Akalin, et al., hypothesized that in many cases, schools simply changed their programs from Operations to Supply Chain Management to keep up with the shift in emphasis in business without actually changing their curriculums (2016).

\subsubsection{Deliver}

Once a product is made it must get to the customer. "The deliver process describes the activities associated with the creation, maintenance, and fulfillment of customer orders" (Blackstone, 2020). In other words, everything that is done to get the products from the manufacturer to the customer. The system shown in Table 6 reflect the necessary systems involved in the distribution or deliver process.

Table 6. Supply Chain Management Systems Required to Support the Deliver Function of the SCOR Model

\begin{tabular}{l|l}
\hline Customer Relationship Management & Order Management Systems \\
\hline Distribution Management Systems & Supply Chain Performance \\
\hline Inventory Management & Transportation Management \\
\hline Materials Requirements Planning (MRP) & Warehouse Management System
\end{tabular}

Like the Make function of the SCOR Model, the Deliver function is covered in the syllabi. However, when the actual numbers of syllabi that include these functions is considered (Distribution management systems is only in one syllabus and Warehouse Management Systems only appear in two syllabi), even though the topics are covered by some of the syllabi, the systems are not adequately covered to ensure that the students will be exposed to the required and commonly used systems.

\subsubsection{Return}

The Return function covers all of the activities associated with reverse logistics or anything that is moving backwards in the supply chain. The systems needed to properly manage the returns processes are shown in Table 7.

Table 7. Systems Required to Support the Returns Function of the SCOR Model

\begin{tabular}{c|c}
\hline $\begin{array}{c}\text { Extend Inventory Planning using } \\
\text { Collaboration (Key Suppliers and } \\
\text { Customers) }\end{array}$ & Continuous Improvement \\
\hline Order Management Systems & Quality Management Systems \\
\hline Warehouse Management Systems & Order Management Systems \\
\hline Distribution Planning Systems & Inventory Management Systems \\
\hline $\begin{array}{c}\text { Electronic Returns Tracking and } \\
\text { Returns Management }\end{array}$ & \\
\hline
\end{tabular}


Traditionally, reverse logistics has not been discussed much in academia or in business. The age-old assumption was that if something was coming back, then something was wrong with the product. The truth is that inventory comes back as over stocked, seasonal, obsolete, damaged or simply that the customer had a change of mind. This tendency to not discuss returns or reverse logistics has helped fuel the shortfall of reverse logistics systems being taught in supply chain management courses. As a result, there are no systems mentioned in any of the syllabi that address returns or reverse logistics issues and management.

\subsection{Limitations}

There are a couple of limitations to this research. The first limitation is the number of syllabi used in the analysis. Future work will include all of the syllabi in the database to determine if other courses may in fact address some of the systems education shortfall. The second limitation is based on the assumption that all of what is taught in a course is reflected in the written and taught curriculums as reflected in a syllabus. This limitation is mentioned only because several faculty members interviewed as part of the 2018 research addressed the time lag between when a syllabus is submitted for approval and the ultimate approval of the syllabus. Therefore, there may be materials covered in the classroom that do not appear on a syllabus.

\section{Recommendations}

What does the analysis show about teaching supply chain management systems? There is a severe shortfall in what academia is teaching in supply chain management systems. If we are going to offer a course in systems, with the exception of one program that was in the sample, we are not doing a good job of covering the different systems that students will see when they leave academia and join the real world of supply chain management. Realizing that companies have customized versions of many off the shelf supply chain management systems, it is not possible to teach every variation of the systems. However, we owe it to our students to cover as many of the systems that they will see as possible.

\subsection{Curriculum Reviews and Curriculum Development}

Pablo Freire in his classic work, Pedagogy of the Oppressed, expressed that we need to expose the students to a wide aspect of topics in order to properly prepare them for the future. Not exposing the students to the systems that they will be working with is, in the words of Freire (1970), doing an injustice to the students. The students may not get exposed to and master every system listed in this study, but the lack of systems taught in the supply chain management systems classes must be improved if academia wants to avoid Freire's injustice in education.

A curriculum review is needed at most schools to ensure that we are exposing the students to more than just an overview of Oracle or SAP. One particular school's systems course appeared to be a "how to" on data entry of SAP with no classes devoted to interpreting the data and making supply chain decisions using the data. Nor does it appear that many schools in the sample set are discussing individual systems used in supply chain management and how the systems are interrelated to provide operations support and to provide critical information for optimization of the entire supply chain. Curriculum reviews need to be detailed, honest and ensure relevant topics, not just in supply chain systems but in all aspects of education.

Curriculum reviews do not have to radically overhaul a program overnight. But curriculum reviews are needed in this discipline on a regular basis to ensure that new systems and new concepts for providing automation support to supply chain operations are added and old outdated systems are removed from the curriculum. The curriculum changes may be small and incremental, but changes are necessary based on the shortfalls shown in this study between what is reported as being taught and what is needed according to industry. Since most supply chain management programs in academia have a core course in systems, this systems curriculum should be reviewed on a regular basis to ensure that we are providing our students with the conditions and foundations for success after graduation.

\section{Future Research and Study}

Future study and research is needed to include more schools in the analysis, but the initial sample of twenty schools shows a shortfall in what students will see and what is being taught to them in the supply chain management systems classes.

\section{References}

Akalin, G. H. (2016). Is Supply Chain Management Replacing Operations Management in the Business School Core Curriculum. Operations and Supply Chain Management, 9(2), 119-130. https://doi.org/10.31387/oscm0240166

ASCM. (2020). Enterprise Certification . Retrieved from ASCM.org: https://www.ascm.org/ascm-enterprisecertification-overview/

Bellamy, M., \& Basole, R. (2012). Network analysis of supply chain systems: A systematic review and future research. Systems Engineering, 16(2), 235-249. https://doi.org/10.1002/sys.21238 
Birou, L. L. (2016). Current state of the art and science: a survey of purchasing and supply chain management courses and teaching approaches. International Journal of Procurement Management, 9(1). https://doi.org/10.1504/IJPM.2016.073388

Blackstone, J. H. (2020). APICS Dictionary, 16th ed. Chicago, IL: APICS.

Chandra, C., \& Kumar, S. (2006). Supply chain design curriculum: models and. International Journal of Information and Operations Management Education, 1(3), 249-280. https://doi.org/10.1504/IJIOME.2006.009718

Field Service. (2020). Supply Chain Management Systems. Retrieved April 16, 2020, from Field Service Events: Supply chain management systems, simply defined, are a network of businesses linked together to provide materials and services to an end user. The goal of these systems is to coordinate functions and strategies, throughout a company, and across businesses.

Freire, P. (1970). Pedagogy of the Oppressed (30th Anniversary Edition). New York: Bloomsbury.

Gilmour, P. (1978). The current status of business logistics education. Transportation Journal, 18(2), 71-78.

Jordan, C., \& Bak, O. (2016). The growing sale an scope of the supply chain: a reflection on supply chain graduate skills. Supply Chain Management: An International Journal, 21(5), 610-626. https://doi.org/10.1108/SCM-02-2016-0059

Kakhki, M., \& Gargeya, V. (2018). Information systems for supply chain management: a systematic literature analysis. International Journal of Production Research, 57(15-16), 5318-5339. https://doi.org/10.1080/00207543.2019.1570376

Li, X., \& Wang, Q. (2007, MAy). Coordination mechanisms of supply chain systems. European Journal of Operational Research, 179(1), 1-16. https://doi.org/10.1016/j.ejor.2006.06.023

Sarimveis, H., Patrinos, P., Tarantilis, C., \& Kiranoudis, C. (2008). Dynamic modeling and control of supply chain systems: A review. Computers \& Operations Research, 35(11), 3530-3561.

https://doi.org/10.1016/j.cor.2007.01.017

Schatte, D. G. (2018). Field Guide to Boot Camp Curriculum Development . Academic Psychiatry, 224-229. https://doi.org/10.1007/s40596-018-0933-3

Sweeney, D., Campbell, J., \& Mundy, R. (2010). Teaching supply chain and logistics management through commercial software. International Journal of Logistics Management, 21(2), 293-308. https://doi.org/10.1108/09574091011071960

Tzu, S. (1993). The Art of War - New Translation. (J. Huang, Trans.) New York: Quill.

Walden, J. (2018). Teaching Supply Chain Management: A qualitative and quantitative approach to developing a supply chain management education framework. Lawrence, KS: University of Kansas. https://doi.org/10.18374/JIMS-183.4

Walden, J. (2019). Developing a common framework and reverse logistics. Reverse Logistics, 100.

\section{Copyrights}

Copyright for this article is retained by the author(s), with first publication rights granted to the journal.

This is an open-access article distributed under the terms and conditions of the Creative Commons Attribution license which permits unrestricted use, distribution, and reproduction in any medium, provided the original work is properly cited. 